\title{
Expression of Fas and TNFR1 in the Luteal Cell Types Isolated from the Ovarian Corpus Luteum
}

\author{
Minseong Kim ${ }^{1, *}$, Sang-Hee Lee ${ }^{2, * *}$, Seunghyung Lee ${ }^{1, * * *}$ and Gur-Yoo Kim ${ }^{1, ;, * * *}$ \\ ${ }^{1}$ College of Animal Life Sciences, Kangwon National University, Chuncheon 24341, Korea \\ ${ }^{2}$ Discipline of ICT, School of Technology, Environments and Design, University of Tasmania, \\ Hobart, Tas7001, Australia
}

\begin{abstract}
The corpus luteum (CL) is composed to various cells, such as luteal steroidogenic cells (LSCs), luteal thecal steroidogenic cells (LTCs), luteal endothelial cells (LECs), fibroblast, immune cells and blood cells. The life span of CL is controlled by proliferation and apoptosis of luteal cells. Therefore, this study investigated apoptotic factors in luteal cells derived from bovine CL. The CL tissues were collected from bovine ovaries and luteal cells were isolated from middle phase CL. Then, LTCs and LECs were separated according to cellular morphology from LSCs. The expression of Bax, Bcl-2, Fas and tumor necrosis factor 1 receptor (TNF1R) mRNA and protein were analyzed using quantitative RT-PCR and western blot. Results show that, Bax and TNFR1 mRNA expression were significantly increased at late group than early and middle groups, otherwise Bcl-2 were significantly decreased at late group than early group $(P<0.05)$. Fas mRNA expression were significantly decreased in middle group compared to early and late groups $(P<0.05)$. In addition, Bax and Bcl-2 mRNA in LTCs was lower than LSCs, Fas mRNA was higher than LSCs. The Bcl-2 protein expression was lower at LTCs than LSCs, especially Fas protein in LTCs was significantly lower than LSCs and LECs $(P<0.05)$. Otherwise, TNFR1 protein of LTCs were similar with LSCs but higher compared with LECs. In conclusion, we suggest that the results may help understanding of apoptosis ability in luteal cells according to cell type during CL regression of estrous cycle.
\end{abstract}

Key Words: Corpus luteum, Luteal steroidogenic cells, Luteal thecal steroidogenic cells, Apoptosis

배란 후 형성되는 황체의 주된 기능은 임신의 유지 와 확립에 필수적인 progesterone $(\mathrm{P} 4)$ 를 분비하는 것이다 (Tomac et al., 2011; Chouhan et al., 2014). 황체는 형성과 퇴 행은 대표적으로 vascular endothelial growth factor (VEGF), tumor necrosis factor $\alpha(\mathrm{TNF} \alpha)$ 에 의해 조절되며 이러한 현 상은 발정주기에 따라 선별적인 성장인자와 호르몬 작용 등의 결과로 이루어진다(Benyo and Pate, 1992; Tamanini and $\mathrm{De}$ Ambrogi, 2004). 일반적으로 황체조직은 P4를 합성하는 luteal steroidogenic cells (LSCs)로 구성되어 있으며 LSCs는
난포 내 granulosa cells (GCs)와 theca cells (TCs)가 배란 후 luteinizing hormone $(\mathrm{LH})$ 에 의해 황체화 된 세포인 large luteal cells (LLCs)와 small luteal cells (SLCs)로 구분된다 (Abulafia and Sherer, 2000). 이외에 황체를 구성하는 세포로 혈관을 형성하는 luteal endothelial cells (LECs)와 fibroblasts, immune cells 등이 있으며 이들 세포는 황체의 생리학적 작용을 유지하는데 이용된다(Schams and Berisha, 2004; Berisha et al., 2016).

황체 내 존재하는 세포는 발정주기에 따라 그들의 형태

Received: November 14, 2018 / Revised: March 12, 2019 / Accepted: March 22, 2019

* Graduate student, ${ }^{* *}$ Researcher, ${ }^{* * *}$ Professor.

†Corresponding author: Gur Yoo Kim. College of Animal Life Sciences, Kangwon National University, Chuncheon 24341, Korea. Tel: +82-33-250-8647, Fax: +82-33-259-5574, e-mail: gykim@kangwon.ac.kr

(C) The Korean Society for Biomedical Laboratory Sciences. All rights reserved.

(c) This is an Open Access article distributed under the terms of the Creative Commons Attribution Non-Commercial License (http://creativecommons.org/licenses/by-nc/3.0/) which permits unrestricted non-commercial use, distribution, and reproduction in any medium, provided the original work is properly cited. 
학적 및 생리학적 특성이 변화된다(Lei et al., 1991). 일반적 으로 LLCs는 배란 후 10 일까지 증식이 일어난 후 멈추게 되며 이후 황체의 성장이 완료되며 그 기능만을 유지하 게 된다(Zheng et al., 1994; Yoshioka et al., 2013). 하지만 임신이 확립되지 않으며 자궁에서 분비되는 prostaglandin $\mathrm{F} 2$ alpha (PGF2 $\alpha$ )에 의하여 황체조직의 퇴행이 일어나는 luteolysis가 발생하며 조직의 형태와 구조가 퇴행하는 구 조적 퇴행(structural regression)과 황체 내에서 분비되는 P4 합성이 줄어드는 기능적 퇴행(functional regression)이 일어 난다(Devoto et al., 2009; Tomac et al., 2011). 실제로 PGF2 $\alpha$ 에 의해 VEGF 및 fibroblast growth factor (FGF) 등과 같은 성장인자의 감소는 황체의 구조적 퇴행을 유도한다고 보 고되었다(Neuvians et al., 2004). 이렇듯 황체 퇴행을 유발 하는 PGF $2 \alpha$ 를 소에 주입하였을 때 12시간 후 황체조직 VEGF와 FGF, VEGF receptor의 mRNA와 protein의 발현이 급감하는 것을 확인하였으며, 황체를 구성하는 혈관세포 의 tumor necrosis factor- $\alpha$ (TNF- $\alpha$ ) 및 interferon $\gamma$ (IFN- $\gamma$ )와 같은 세포사멸과 관련된 cytokine을 증가시켜 luteolysis를 유도한다는 보고가 있다(Davis and Rueda, 2002). 따라서 본 연구에서는 소 황체조직과 이를 구성하는 황체세포에서 apoptosis와 관련된 인자들을 분석하기 위해 발정주기 별 황체조직과 이로부터 분리된 steroidogenic 기능과 theca cell의 특성을 지니고 있는 luteal thecal steroidogenic cell (LTCs), LSCs 및 LECs를 이용하여 apoptosis 관련 인자들 을 분석하였다.

실험에 사용한 동물실험은 강원대학교 동물실험윤리위 원회의 승인(KTACUC-17-109)을 받아 윤리적으로 수행하 였으며, 소 황체를 수집하기 위하여 인근 도축장에서 도 축된 한우에서 난소를 $4{ }^{\circ} \mathrm{C}, 0.85 \%$ 생리식염수 보관 하에 2 시간 이내 실험실로 운반되었다. 이 후 난소는 이전의 거 시적인 형태학적인 방법으로 각각 초기, 중기 및 후기를 구분하였으며 난소에서 황체만을 분리하여 실험에 이용하 였다(Miyamoto et al., 2000; Kim et al., 2018). 황체세포는 중 기 황체로부터 분리하였으며 세포 분리를 위하여 세절된 황체조직을 $0.65 \mathrm{mg} / \mathrm{mL}$ collagenase A (Roche, Switzerland) 및 $50 \mathrm{U} / \mathrm{mL}$ DNase I (MGmed, Korea)가 첨가된 Dulbecco Modified Eagle Medium (DMEM; Sigma, USA)에서 $30^{\circ} \mathrm{C}$ 에서 90분간 교반한 후 DMEM/Nutrient Mixture F-12 (D/ F12; Sigma)에 10\% Fetal bovine serum (FBS; Cellgro)가 함유 된 배양액을 첨가한 뒤 필터로 거른 현탁액을 원심분리 $(1,800 \mathrm{rpm}, 10$ 분)하여 상층액을 제거하였다. 이 후 세포배 양액(D/F12 + 10\% FBS)을 첨가한 후 $100 \mathrm{~mm}$ culture dish
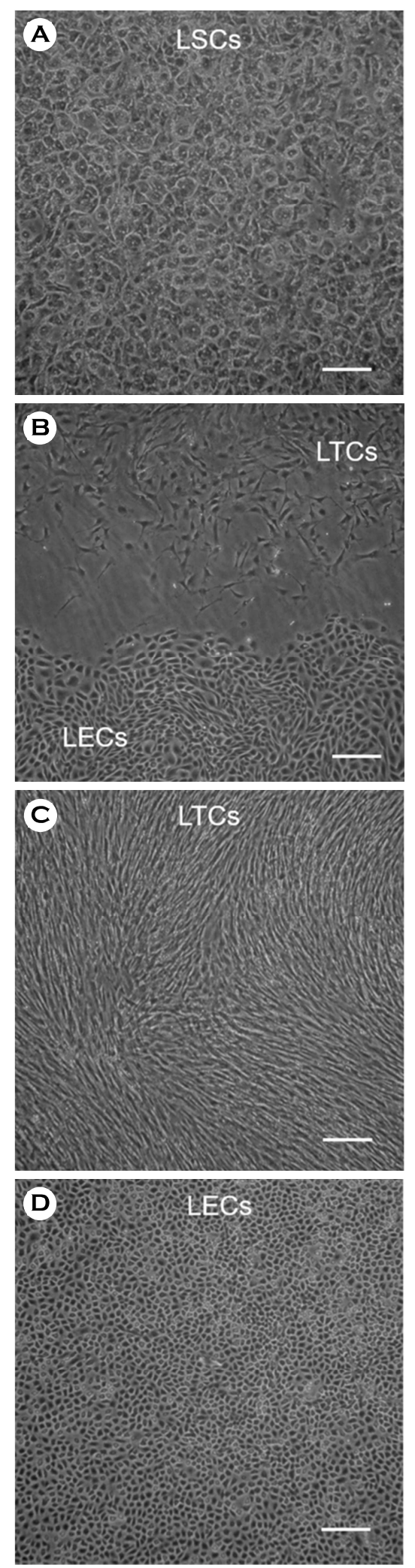

Fig. 1. Morphological characteristics of LSCs (A), growing LTCs (B, upper area) and LECs (B, lower area), isolated LTCs (C), and LECs (D), White scale bar, $200 \mu \mathrm{m}$. 
(NUNC, USA)에 분주한 뒤 $38.5^{\circ} \mathrm{C}, 5 \% \mathrm{CO}_{2}$ 에서 16 24시 간 때 부착된 세포만을 LSCs (Fig. 1A)로 판단하였다. 이후 증식하는 세포의 morphology (Fig. 1B)를 기준으로 LTCs (Fig. 1C) 및 LECs (Fig. 1D)를 구별한 후 cylinder를 이용하 여 분리 배양 후 실험에 이용하였다(Fig. 1).

황체조직과 세포의 mRNA는 RNAiso Plus (Takara, Japan) 를 이용하여 추출한 후 cDNA synthesis kit (Takara)를 이용 하여 cDNA를 합성하였다. 합성된 cDNA는 TNFR1 (5' ACT GGT GCT TCC AGC TCT GT 3' 및 5' CTC CAC CTG GAA CAT TTC GT 3'), Fas (5' CAG GAG GGC CCA TAA ACT GTT TGC 3' 및 5' ATG GGC TAG AAG TGG AAC AAA AC 3'), Bax (5' TTT GCT TCA GGG TTT CAT C 3' 및 5' CAG CTG CGA TCA TCC TCT 3') 및 Bcl-2 (5' CTG CAC CTG ACG CCC TTC AC 3' 및 5' GCG TCC CAG CCT CCG TTG T 3')와 함께 PCR premix kit (Bioneer, South Korea)를 이용하여 PCR을 수행하였으며 산물은 $1.5 \%$ agarose gel을 이용하여 $100 \mathrm{~V}$ 에서 20분 동안 전기영동 후 UV에 노출 시켜 이미지를 수집한 후 Image J software 프로그램(NCBI, USA)을 이용하여 발현양을 분석하였다.

황체세포의 단백질 분석은 기존 방법을 응용하여 분석 하였다(Han et al., 2017). $25 \mu \mathrm{g}$ 의 단백질을 acrylamide gel을 이용하여 전기영동을 실시한 후 polyvinylidene difluoride (PVDF) membrane으로 transfer를 실시한 뒤 1시간 동안 blocking을 실시하였다. 실험에 사용된 항체는 Santa Cruz Biotechnology의 제품을 이용하였으며 1차 항체는 mouse monoclonal anti-Bax (sc-23959), mouse monoclonal anti-Bcl-2 (sc-7382), mouse monoclonal anti-Fas (sc-74540), mouse monoclonal anti-TNFR1 (sc-8436) 및 mouse monoclonal $\beta$-actin (sc-47778)을 1:500으로 희석하여 $4{ }^{\circ} \mathrm{C}$ 에서 $\mathrm{O} / \mathrm{N}$ 시켰으며 2 차 항체는 $1: 10,000$ 으로 희석된 goat-anti-mouse IgG-HRP (sc-2005)를 이용하여 암실에서 1시간 동안 실온에서 반응 시켰다. 단백질 가시화를 위하여 ECL kit (Thermo Scientific, USA)를 사용하였으며 EZ-capture II Chemidoc (ATTO, Japan) 을 사용하여 시각화한 후 ImageJ를 이용하여 발현양을 수치화 하였다.

실험에서 얻어진 결과는 통계 프로그램(SPSS, USA)을 이용하여 최소 유의차 검정(Least Significant Different test; LSD test)을 적용한 Duncan의 multiple range test에 의해 유 의차 $(P<0.05)$ 검정을 실시하였다.

발정주기에 따른 황체조직에서 세포사멸 관련 인자 발 현 차이를 확인하기 위해 발정주기 별 조직에서의 TNFR1, $\mathrm{Fas}, \mathrm{Bax}$ 및 Bcl-2 mRNA의 분석한 결과를 Fig. 2에 나타 내었다. Bax와 TNFR1은 초기(Early) 및 중기(Middle)에 비 하여 후기(Late)에서 유의적으로 증가하였으며 Bcl-2는 초 기에 비하여 중기 및 후기에서 유의적으로 감소하였다 $(P<0.05)$. 또한 Fas mRNA는 중기에서 유의적 $(P<0.05)$ 으 로 감소하였으나 초기 및 후기에서 유의적인 차이가 나타 나지 않았다(Fig. 2). 일반적으로 황체는 임신이 성립되지 않으면 자궁에서 분비되는 $\mathrm{PGF} 2 \alpha$ 에 의하여 구조적 및 기 능적 퇴행과 함께 apoptosis가 진행된다(Stocco et al., 2007). 황체가 퇴행하는 luteolysis가 일어나는 동안에는 apoptosis 세포 신호 중 대표적으로 알려져 있는 TNF receptor 1
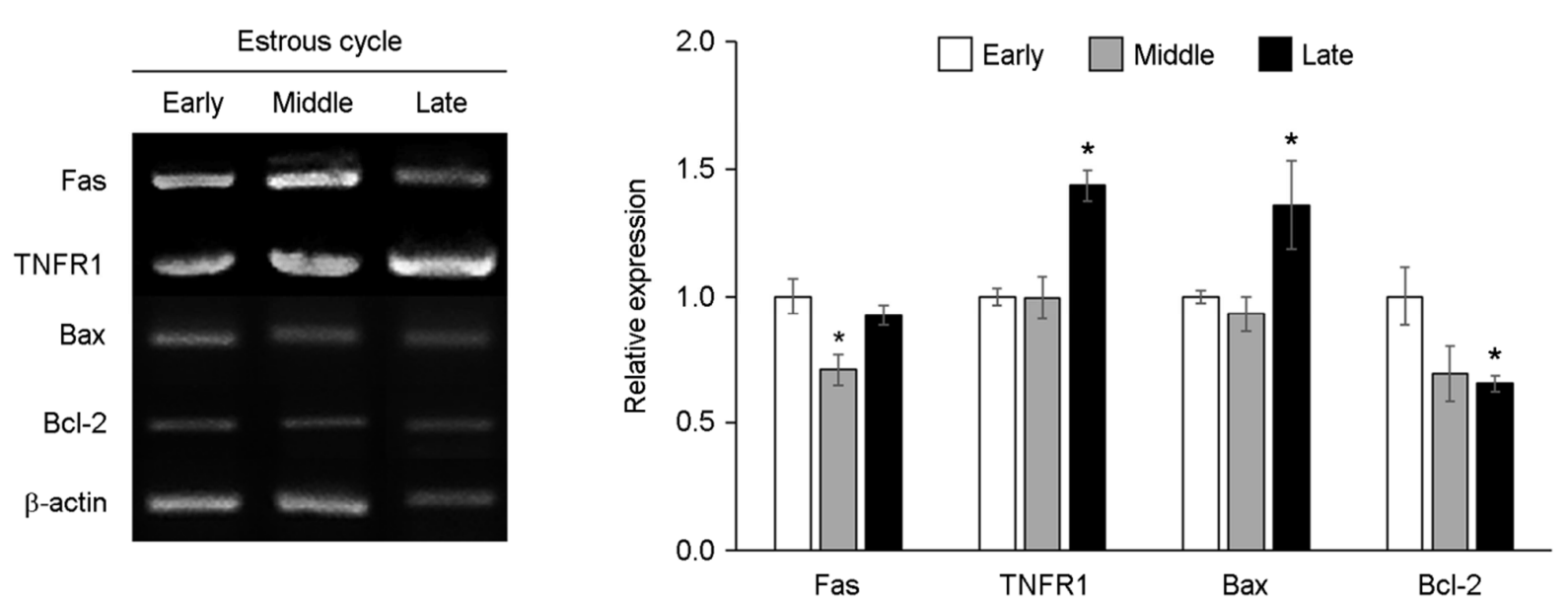

Fig. 2. Change of Bax, Bcl-2, Fas and TNFR1 mRNA expression during estrous cycle in corpus luteum, corpus luteum tissues were classified to early, middle and late according to morphology and genes expression of middle and late tissues was normalized to early group. $* P<0.05$. 
(TNFR1)과 Fas가 활성화 된다(Penny et al., 1999; Taniguchi et al., 2002). 본 연구결과에서도 조직의 증식이 활발하게 일어나는 초기 황체조직에는 TNFR1 mRNA가 감소하였 나 퇴행이 일어나는 후기에는 apoptosis 수용체의 발현양 이 증가한 것을 확인하였다. 실제로 $\mathrm{TNF} \alpha \mathrm{mRNA}$ 는 배란 후 13 18일 이후 퇴행기의 황체조직에서 증가한다고 보 고(Sakumoto et al., 2000)하였으며, 본 실험에서는 후기 황 체에서 TNFR 1 의 mRNA가 증가하였는데 이는 $\mathrm{TNF} \alpha$ 의 작용이 활발하기 위한 것이라 판단된다. 또한 황체 표면 에 존재하는 Fas는 면역세포에 존재하는 Fas Ligand (FasL) 와 결합하여 황체세포의 apoptosis를 유발한다고 알려져
있다(Stocco et al., 2007). 실제로 황체 후기에는 면역세포들 의 증가에 의한 황체 퇴행이 증가하며 이에 따라 퇴행기 의 황체에는 Fas와 FasL의 활동이 증가된다고 보고되었다 (Kuranaga et al., 2000). 본 연구결과에서는 조직의 재구성 이 왕성하게 일어나는 초기와 luteolysis가 급격하게 일어 나는 후기에 Fas mRNA의 양이 증가하였는데 이러한 결 과는 기존의 보고된 결과와 일치한 것을 확인하였다. 이 후 원형질막에 위치하여 apoptosis 세포 신호를 유발하는 인자들에 의해 증가하는 미토콘드리아 의존적 apoptosis 인자들인 $\mathrm{Bax}$ 및 $\mathrm{Bcl}-2$ 중 TNFR1 및 $\mathrm{Fas}$ 가 증가하는 후 기에 $\mathrm{Bax}$ 는 증가하였으며 $\mathrm{Bcl}-2$ 는 감소하였다. 이러한 결
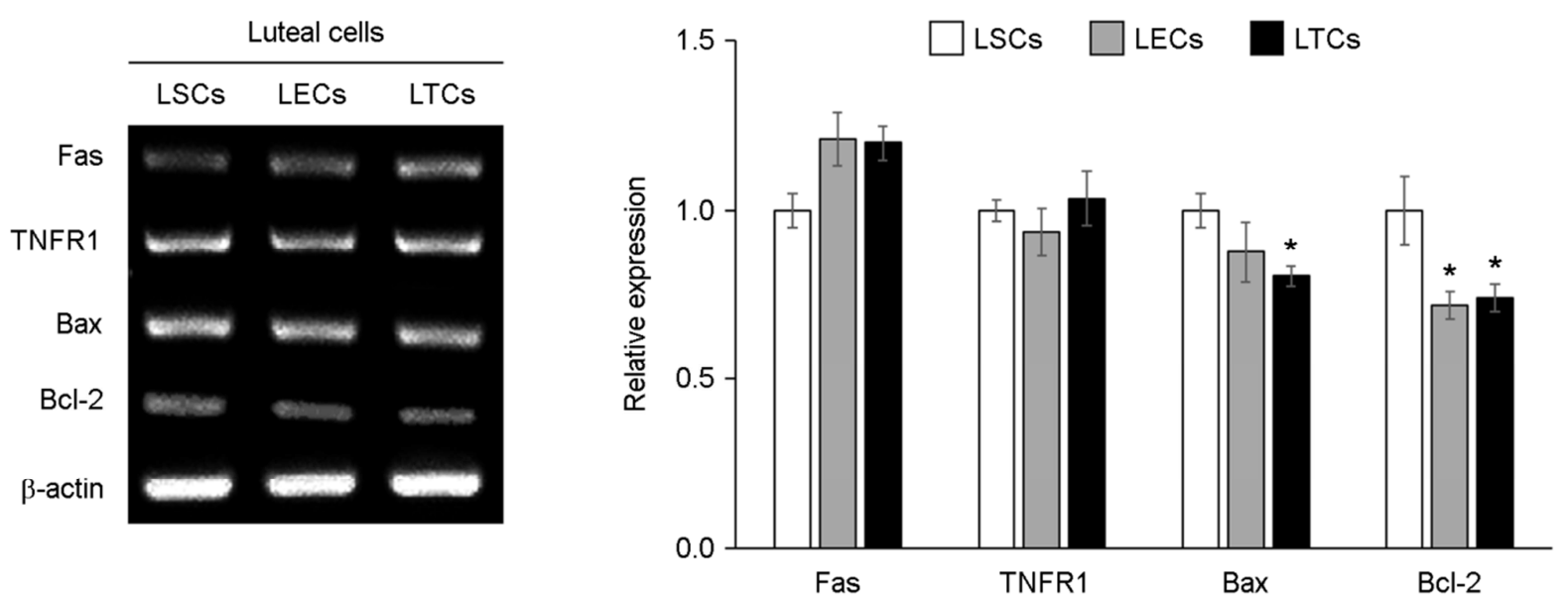

Fig. 3. Change of Bax, Bcl-2, Fas and TNFR1 mRNA expression in LSCs, LECs, and LTCs, luteal cells were isolated from middle phase corpus luteum. Genes expression of LECs and LTCs was normalized to LSCs group. ${ }^{*} P<0.05$.
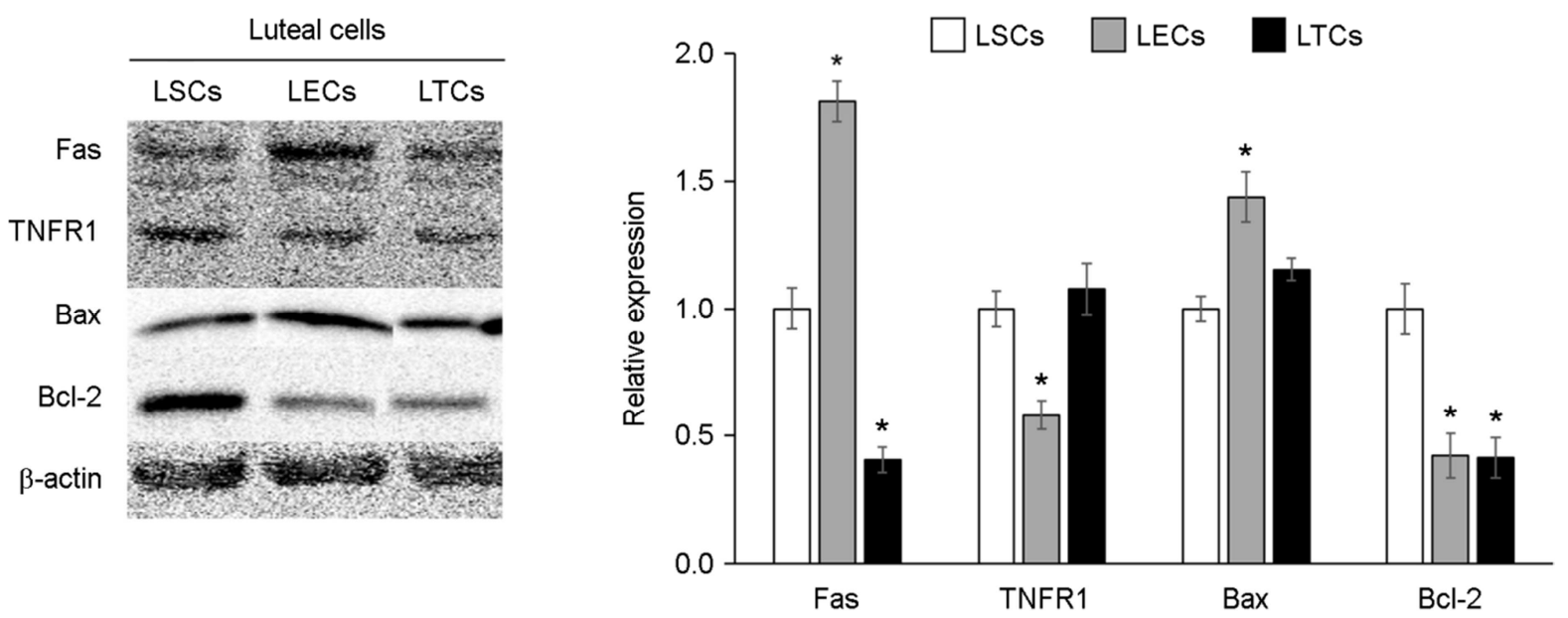

Fig. 4. Change of Bax, Bcl-2, TNFR1 protein expression in LSCs, LECs, and LTCs, luteal cells were isolated from middle phase corpus luteum. Protein intensity of LECs and LTCs was normalized to LSCs group. $* P<0.05$. 
과는 황체조직에서 luteolysis가 일어날 때 미토콘드리아 의존적 apoptosis도 cytokine apoptosis 수용체들에 의해 활 성화 된다고 판단된다.

발정주기 별 황체조직에서 apoptosis 수용체들과 미토콘 드리아 의존적 apoptosis 인자들을 확인한 후 황체를 구성 하는 다양한 세포 별로 apoptosis와 관련된 인자들을 분석 하기 위하여 중기 황체로부터 분리한 황체세포에서 세포 사멸 mRNA 및 protein 발현을 Fig. 3 및 4에 나타났다. $\mathrm{Bax}$ 와 $\mathrm{Bcl}-2$ 의 mRNA 발현은 LSCs에서 LTCs와 LECs보 다 높은 수준으로 발현되었고, Fas mRNA는 LTCs와 LECs 에서 LSCs보다 높게 발현된 것으로 확인되었으며, TNFR1 의 경우 세포 별 mRNA 발현에 있어 유의적인 차이가 확 인되지 않았다(Fig. 3). Bax와 Fas의 protein 발현은 LECs에 서 LSCs와 LTCs보다 높은 수준으로 확인되었다. Bcl-2는 mRNA와 같은 패턴이 확인되었다. TNFR1 protein은 LECs 에서 적게 발현되었고, LSCs와 LTCs의 발현에는 차이가 확인되지 않았다(Fig. $4, P<0.05)$. 황체의 luteolysis는 이를 구성하는 세포들의 사멸로부터 시작된다(Schams and Berisha, 2004; Tomac et al., 2011; Shirasuna et al., 2012). 황체는 주로 LSCs 및 LECs 두 가지 타입의 세포에 의하여 구조와 기 능이 유지된다고 보고되어 있기 때문에 이에 대한 연구 는 활발하게 이루어지고 있다(Skarzynski and Okuda, 1999; Davis et al., 2003; Lee et al., 2010). 또한 LSCs 이외에도 $\mathrm{LECs}$ 역시 PGF $2 \alpha$ 수용체를 갖고 있기 때문에 황체 퇴행 기에서 분비되는 PGF $2 \alpha$ 에 의하여 세포사멸이 일어난다 (Gwon et al., 2013). 본 연구에서는 LSCs에서 TCs의 성 격을 띠고 있고 steroidogenic 기능을 갖고 있는 황체 내 LTCs를 분리하여 실험에 이용하였고 이러한 세포는 황체 내 존재하며 LSCs 내에 적은 비율로 포함되어 있으나 $\mathrm{LECs}$ 처럼 증식을 하기 때문에 본 연구에서는 $\mathrm{LSCs}$ 와는 구분되는 세포로 판단한 후 실험에 이용하였다. 실제로 TNFR1, Fas, Bax 및 Bcl-2 발현에 있어 LTCs는 LSCs와 서 로 다른 양상으로 mRNA 및 protein이 발현되었고 실험 결과를 통해 TNFR1로부터 시작되는 apoptosis는 LECs에 비하여 LSCs 및 LTCs에서 더욱 활발히 일어날 수 있음 을 알게 되었다. 하지만 Fas의 경우 다른 세포들에 비하 여 LTCs에서 적게 발현되었는데 이는 황체 퇴행 시 면역 세포의 FasL가 LSCs 및 LECs에 비하여 LTCs가 더 적게 반응할 것이라 판단된다. 실제로 황체로부터 분리한 SLCs 의 경우 LLCs에 비해 Fas mRNA의 양이 적게 발현되었 다는 보고(Kuranaga et al., 2000)가 있었으나 LECs와 비교 하지는 않았기 때문에 본 실험에서 사용된 LTCs의 경우
Fas 발현에 있어 SLCs와 비슷한 경향을 보이나 LECs와 의 비교가 되지 않았기 때문에 이 후 LTCs에 대한 추가적 인 실험이 필요하다고 판단된다.

따라서 본 실험을 통하여 LTCs는 황체 내 존재하며 LSCs 내 적은 비율로 포함된 세포임을 확인하였다. 또한 LTCs는 LSCs와 다르게 apoptosis에 있어 Fas에 대한 반응 이 적은 반면 TNFR1의 반응은 비슷한 것으로 판단된다. 반면 apoptosis와 관련된 유전자 발현은 LECs와 비슷한 양상을 보이나 단백질 발현의 경우 LECs에 비하여 Fas 발현은 적은 반면 TNFR1는 많은 것을 확인할 수 있었다. 결론적으로 황체 내 존재하며 steroidogenic 기능을 하며 증식성을 갖고 있는 LTCs는 황체 퇴행 시 발생하는 apoptosis에 있어 LSCs 및 LECs와는 다른 세포 신호가 존재 할 것이라 판단된다. 향후 추가적인 실험을 통하여 LTCs 에서 특이적으로 발현되는 세포부착인자 및 small G protein 연구결과를 기반으로 황체 퇴행의 메커니즘에 적용 한다면 황체 내 apoptosis에 대한 기초적인 연구에 도움을 줄 것이라 판단된다.

\section{ACKNOWLEDGEMENT}

This research was supported by Basic Science Research Program through the National Research Foundation of Korea (NRF) funded by the Ministry of Education (2018R1D1A3B07048167). This study was supported by 2017 Research Grant from Kangwon National University (No. D1001265-01-01).

\section{CONFLICT OF INTEREST}

No potential conflict of interest relevant to this article was reported.

\section{REFERENCES}

Abulafia O, Sherer DM. Angiogenesis of the ovary. American Journal of Obstetrics and Gynecology. 2000. 182: 240-246.

Benyo DF, Pate JL. Tumor necrosis factor-alpha alters bovine luteal cell synthetic capacity and viability. Endocrinology. 1992. 130: 854-860.

Berisha B, Schams D, Rodler D, Pfaffl MW. Angiogenesis in the ovary-the most important regulatory event for follicle and corpus luteum development and function in cow-an overview. Anatomia, Histologia, Embryologia. 2016. 45: 124-130.

Chouhan V, Dangi S, Gupta M, Babitha V, Khan F, Panda R, Yadav V, Singh G, Sarkar M. Stimulatory effect of vascular endothelial 
growth factor on progesterone production and survivability of cultured bubaline luteal cells. Animal Reproduction Science. 2014. 148: 251-259.

Davis JS, Rueda BR. The corpus luteum: An ovarian structure with maternal instincts and suicidal tendencies. Frontiers in Bioscience. 2002. 7: d1949-d1978.

Davis JS, Rueda BR, Spanel-Borowski K. Microvascular endothelial cells of the corpus luteum. Reproductive Biology and Endocrinology. 2003. 1: 89.

Devoto L, Fuentes A, Kohen P, Céspedes P, Palomino A, Pommer R, Muñoz A, Strauss III JF. The human corpus luteum: Life cycle and function in natural cycles. Fertility and Sterility. 2009. 92: 1067-1079.

Gwon SY, Rhee KJ, Lee S. Endothelial cells isolated from the bovine corpus luteum synthesize prostaglandin $\mathrm{f} 2 \alpha$ receptor. Biomedical Science Letter. 2013. 19: 261-265.

Han H-I, Lee S-H, Park C-K. Development of in vitro embryo production system using collagen matrix gel attached with vascular endothelial growth factor derived from interleukin-1 beta-treated porcine endometrial tissue. Tissue Engineering Part C: Methods. 2017. 23: 396-403.

Kim M, Lee S-H, Lee S. Expression of H-ras, RLIP76 mRNA and protein, and angiogenic receptors in corpus luteum tissues during estrous cycles. Korean Journal of Clinical Laboratory Science. 2018. 50: 457-461.

Kuranaga E, Kanuka H, Furuhata Y, Yonezawa T, Suzuki M, Nishihara M, Takahashi M. Requirement of the fas ligandexpressing luteal immune cells for regression of corpus luteum. FEBS Letters. 2000. 472: 137-142.

Lee S, Acosta TJ, Nakagawa Y, Okuda K. Role of nitric oxide in the regulation of superoxide dismutase and prostaglandin $\mathrm{f} 2 \alpha$ production in bovine luteal endothelial cells. Journal of Reproduction and Development. 2010. 56: 454-459.

Lei Z, Chegini N, Rao CV. Quantitative cell composition of human and bovine corpora lutea from various reproductive states. Biology of Reproduction. 1991. 44: 1148-1156.

Miyamoto Y, Skarzynski DJ, Okuda K. Is tumor necrosis factor $\alpha$ a trigger for the initiation of endometrial prostaglandin $\mathrm{f} 2 \alpha$ release at luteolysis in cattle? Biology of Reproduction. 2000. 62: 1109-1115.

Neuvians T, Berisha B, Schams D. Vascular endothelial growth factor (vegf) and fibroblast growth factor (fgf) expression during induced luteolysis in the bovine corpus luteum. Molec- ular Reproduction and Development. 2004. 67: 389-395.

Penny L, Armstrong D, Bramley T, Webb R, Collins R, Watson E. Immune cells and cytokine production in the bovine corpus luteum throughout the oestrous cycle and after induced luteolysis. Journal of Reproduction and Fertility. 1999. 115: 87-96.

Sakumoto R, Berisha B, Kawate N, Schams D, Okuda K. Tumor necrosis factor- $\alpha$ and its receptor in bovine corpus luteum throughout the estrous cycle. Biology of Reproduction. 2000. 62: 192-199.

Schams D, Berisha B. Regulation of corpus luteum function in cattle-an overview. Reproduction in Domestic Animals. 2004. 39: 241-251.

Shirasuna K, Nitta A, Sineenard J, Shimizu T, Bollwein H, Miyamoto A. Vascular and immune regulation of corpus luteum development, maintenance, and regression in the cow. Domestic Animal Endocrinology. 2012. 43: 198-211.

Skarzynski DJ, Okuda K. Sensitivity of bovine corpora lutea to prostaglandin $\mathrm{f} 2 \alpha$ is dependent on progesterone, oxytocin, and prostaglandins. Biology of Reproduction. 1999. 60: 1292-1298.

Stocco C, Telleria C, Gibori G. The molecular control of corpus luteum formation, function, and regression. Endocrine Reviews. 2007. 28: 117-149.

Tamanini C, De Ambrogi M. Angiogenesis in developing follicle and corpus luteum. Reproduction in Domestic Animals. 2004. 39: 206-216.

Taniguchi H, Yokomizo Y, Okuda K. Fas-fas ligand system mediates luteal cell death in bovine corpus luteum. Biology of Reproduction. 2002. 66: 754-759.

Tomac J, Cekinović Đ, Arapović J. Biology of the corpus luteum. Periodicum Biologorum. 2011. 113: 43-49.

Yoshioka S, Abe H, Sakumoto R, Okuda K. Proliferation of luteal steroidogenic cells in cattle. PLoS One. 2013. 8: e84186.

Zheng J, Fricke PM, Reynolds LP, Redmer DA. Evaluation of growth, cell proliferation, and cell death in bovine corpora lutea throughout the estrous cycle. Biology of Reproduction. 1994. 51: 623-632.

https://doi.org/10.15616/BSL.2019.25.1.107

Cite this article as: Kim M, Lee SH, Lee S, Kim GY. Expression of Fas and TNFR1 in the Luteal Cell Types Isolated from the Ovarian Corpus Luteum. Biomedical Science Letters. 2019. 25: 107-112. 